\title{
Nogeens: Die agtergrond, inhoud en implikasies van die Gelofte van 1838
}

Piet Strauss

Universiteit van die Vrystaat

Bloemfontein

\begin{abstract}
Once more: The background, contents and implications of the Vow of 1838

The vow taken by the so-called Voortrekkers before the Battle of Bloodriver in Natal on the 16th December 1838 against the Zulu impis remains a much-debated topic. In this article the author enters into dialogue with some results of recent research. Themes such as the degree to which the vow is binding on descendants, the sabbatical character of the day of commemoration and the implications of the views behind the vow for reconciliation in the present South Africa, are discussed. The conclusion is that the vow is based on sound Christian principles, morally binding on Christian Afrikaners and those who see fit to associate with them, and in principle not a stumbling block in the way of reconciliation in a South Africa based on Christian values.
\end{abstract}

\section{SAAK BLY AKTUEEL}

Die debat oor die gelofte wat die Emigrante-Boerekommando van Andries Pretorius in 1838 op die vooraand van die Slag van Bloedrivier afgelê het, bly aktueel. Hierdie aktualiteit vergestalt homself hoofsaaklik op twee fronte: die vraag na die implikasies van hierdie gelofte vir veral die Afrikaner van 2000 én of die tradisionele viering van Geloftedag wat in Suid-Afrika tans amptelik Versoeningsdag heet, nie juis vir 'n soort amptelike versoeningsdag - sy dit ook op Christelike grondslag - plek moet maak nie. Eintlik hang die twee vrae met mekaar saam. 
As jy as Christen of Christen-Afrikaner bereid is om 16 Desember 1838 daar te laat, sal jy jou waarskynlik makliker met 'n dag van versoening los van hierdie geskiedenis inlaat.

Aan die ander kant leef daar onder sekere Christen-Afrikaners die cortuiging dat die regte verstaan van die gelofte van 1838 nie Christelike versoening in Suid-Afrika uitsluit nie, maar die regte basis daarvoor suggereer. Die gelofte van 1838 en Geloftefees as 'n viering van hoofsaaklik Afrikaners, hoef op hierdie standpunt nie plek te maak vir 'n dag met 'n nuwe inhoud nie, maar kan hom eietyds ook toespits op versoening tussen Christen-Afrikaners en ander in hierdie land. So kan dit 'n bydrae van die tradisionele vierders van hierdie dag tot algemene versoening verteenwoordig. Wat meer is, so lui die argument, die gelofte van 1838 was 'n gelofte aan God met ernstige gevolge vir die "opkomende geslagte" van hulle wat daarby betrokke was - aanstons meer oor wat hieronder verstaan moet word - en kan nie ligweg laat vaar word nie (NGK 1994:437; 1998:419).

Dan is daar ook diegene wat die politieke en sosiaal-ekonomiese verwikkelinge van die afgelope kwarteeu in Suid-Afrika as 'n versaking van die betekenis van die gelofte van 1838 verwerp. En 'n aanvaarding van die idee van 'n dag van versoening is volgens hulle 'n tipiese kniebuiging voor hierdie tendense (Van den Berg 1999:10ev). Professor Schalk Botha, ons jubilaris, het hom eweneens nie in hierdie debat onbetuig gelaat nie (vgl Botha 1988; Van den Berg \& Botha 1994). Daarom wil ek aanvaar dat 'n verdere bydrae, 'n "nogeens ..." in hierdie saak, hom sal interesseer. Dit is juis 'n aantal resente "nogeense" van ander oor die gelofte van 1838 wat hierdie artikel én nogeense besinning oor aspekte van die tema tot gevolg gehad het (vgl NGK 1994; 1998; Van den Berg \& Botha 1994; Marais 1996; Van den Berg 1999).

Om die kwessies op beide genoemde fronte te belig, is toeligting van die agtergrond sowel as die inhoud van die gelofte van 1838 nodig. Sodoende sal ons die implikasies en eietydse toespitsing daarvan ook nader kan aandui. 


\section{GODSDIENSTIGE AGTERGROND VAN DIE GELOFTE VAN} 1838

\subsection{Die Nadere Reformasie}

Kennis van bestaande literatuur oor die gelofte van 1838 toon dat Pont gelyk het as hy in 1988 beweer dat daar tot op daardie stadium nog nie 'n poging was om die gelofte te plaas teen die godsdiens-historiese agtergrond en verstaan van 'n gelofte deur die Voortrekkers - hulle word eers sedert die 1870's so genoem (Du Bruyn 1986:127) - self nie (1988:38). Pont het ook gelyk as hy hierdie agtergrond in die Nederlandse Nadere Reformasie gaan soek. Die invloed van hierdie beweging met sy sogenaamde oude schrijvers op die destydse emigrante is elders oortuigend aangetoon (Brown 1990:533554; De Jongh 1977:118; 1987:80).

Die Nadere Reformasie kan as die Nederlandse verskyningsvorm van die Europese piêtisme van die 17e en 18e eeu getipeer word. Die Engelse weergawe hiervan vind ons in die puritanisme en die Duitse weergawe gewoon in die Duitse piětisme. Hierdie tweede reformasie beoog die radikale deurwerking van die 16e eeuse Hervorming en oriênteer histories en andersins op Calvyn. Dit lê klem op die innerlike belewing van die gereformeerde leer en op persoonlike lewensheiliging as heiliging op alle terreine (Van 't Spijker 1986:5-6). Dit wil die suiwere gereformeerde leer handhaaf met "heel het volk onder heel het Woord" (Van "t Spijker 1986:15). Dit beoog die reformasie van die vaderlandse kerk én die hele maatskappy of volkslewe (Van 't Spijker 1986:9; Malan 1984:3).

Die Nederlandse samelewing van die $17^{\circ}$ en $18^{e}$ eeu is beheers deur die beskouing van die samelewing as 'n teokratiese verbondsgemeenskap. Die uitgangspunt was dat alle burgers gedoop is, binne die genadeverbond van God lewe, en dus aan die eise van hierdie verbond moet voldoen. Kerk en staat was twee kante van dieselfde gemeenskap: die lidmate van die kerk was ook die burgers van die staat. Benewens die feit dat die staatsowerheid moes sorg dat die eer van God in die openbare lewe gehandhaaf word en dat niks die ware diens van God belemmer nie, moes hy ook die staatsapparaat gebruik om die ware Christelike godsdiens te bevorder. 
Hierdie siening van die samelewing as 'n teokratiese verbondsgemeenskap is deur die Nadere Reformasie gedeel en haak in by die opvattinge van Calvyn soos toegepas in die stadstaat van Genevé. Dit blyk verder die agtergrond te wees vir artikel 36 van die Nederlandse Geloofsbelydenis van 1561 wat onder die invloed van die Geneefse hervormer staan. Artikel 36 vind sy neerslag in die proklamasie van die Nasionale Vergadering van die sewe Verenigde Provinsies van die Nederlande in 1651. Hierin word verklaar dat hierdie owerheid vashou aan die "ware Christelijke religie" wat “...met de macht van 't Land sal ghehandhaeft worden" (Pont 1986:36, 37, 41).

\subsection{Teokrasie na die Kaap}

Dieselfde siening is deur die VOC of Kompanjie sedert 1652 na die Kaap corgedra. As handels- en owerheidsorgaan het die VOC in 1622 die opdrag gekry om die gereformeerde godsdiens van die "openbare" kerk in Nederland te handhaaf (Van der Watt 1986:4). Daarom het Van Riebeeck in sy gebed by die aan-wal-gaan in 1652 ook die voortplanting en uitbreiding van die ware gereformeerde Christelike leer in die vooruitsig gestel (Olivier 1990:16). Die Kompanjie sou aan die Kaap die geestelike versorging van sy onderdane onderneem en predikante en sieketroosters aanstel, taak en besoldig (Van der Watt 1986:7). Tot ongeveer 1780 was die Gereformeerde (Ned Geref) Kerk die enigste "openbare" kerk wat deur die politieke owerheid aan die Kaap toegelaat is. Kommisarisse-politiek het kerkraadsvergaderinge bygewoon en 'n geval is bekend waar die kerkraad van Tulbach die Politieke Raad in 1743 versoek het om lidmate te verplig om hulle kinders te doop in die gemeente binne wie se grense hulle val (Van der Watt 1986:67-68).

Ook by die Emigrante-Boere op die trekpad van 1835-1840 werk hierdie teokratiese opvatting deur. So lê goewemeur Piet Retief op 11 Junie 1837 aan die Vetrivier 'n aanvullende eed in die kerk af waarin hy onderneem om met alles in te stem wat tot heil van volk en kerk strek. Hierdie kerk is die "Nederduitsche Gereformeerde Kerk" wat, aldus die eed, op grond van artikel 36 van die Nederlandse Geloofsbelydenis deur die hoof van die Trekkerstaat ten opsigte van sy belydenisse en liturgieě beskerm sal word. Verder beloof die goewerneur om niemand in die kerklike of burgerlike regering van die emigrantemaatskappy aan te stel wat nie lidmaat van "voormelde" gereformeerde 
kerk is nie. Volgens die Voortrekkerpredikant, Erasmus Smit, was hierdie aanvullende eed nodig omdat 'n kerklike inhuldiging die staatshoof en sy opvolgers verbind tot waaksaamheid teen "vervalsing" en tot hulp met die voortgang van die kerk - alles na die voorbeeld van "onzer vrome voorvaderen" (Smit 1897:26). Die oriëntering is duidelik op artikel 36 en die Nederlandse geloofsvaders.

Hoe vervleg kerk en staat as twee kante van dieselfde gemeenskap hier funksioneer, word ook geillustreer in die eerste artikel van die Vetrivierse "grondwet" wat op 17 April aanvaar word. Dié artikel begin met "Wij de gerefformeerde Leedematen..." (Preller 1920:300).

Dit is 'n vraag of die Skotse presbiterianisme en Engelse puritanisme nie ook sedert die 1820's op hierdie teokratiese opvattings van die Voortrekkers ingewerk het nię. Puriteinse beïnvloeding van die Nadere Reformasie is reeds aangetoon (Hofmeyr 1989:22). Daarby vergelyk die inhoud van artikel 36 soos genoem goed met artikel 34 van die Skotse Belydenis van 1560 (Schaff III 1983:474) en artikel 23 van die puriteinse Westminsterbelydenis van 1647 (Schaff III 1983:653).

Dat hierdie soort beĭnvloeding kon plaasgevind het, kan nie uitgesluit word nie. Wat die trekkers self betref, het hulle egter doelbewus op Nederland en die ou skrywers van die Nadere Reformasie georiènteer. Smit se "vrome voorvaderen" en verwysing na artikel 36 bevestig dit. So ook die keuse van die naam vir hulle emigrantestaat in 1837: De Vrije Provincie van Nieuw Holland in Zuid Oost Afrika (Smit 1897:24).

Hierdie orięntering sou ook blyk uit uit die direkte godsdienstige agtergrond van die gelofte van 1838.

\subsection{Nadere Reformasie en gelofte van 1838}

Sonder om nou reeds die teks van die gelofte van 1838 in behandeling te neem, kan dit gesê word dat hierdie gelofte in sy bewoording baie duidelik bloot 'n verbond of ooreenkoms tussen diegene wat dit aflê en die Here daarstel. Dit gaan hier om 'n ernstige versoek dat die Here aan die Voortrekkers die oorwinning oor hulle vyande sal gee en hulle gelofte dat hulle in antwoord hierop sekere handelinge sal uitvoer. Dit is 'n ooreenkoms tussen hulle en God. 
Die bekende Skotse en puriteinse covenants - wat eweneens vanuit 'n reformatoriese teokratiese verbondsteologie opereer - verskil in hierdie opsig met die gelofte van 1838 deurdat hulle 'n coreenkoms tussen die gedoopte volk onderling teen 'n gemeenskaplike bedreiging, maar vóór God daarstel. Dit geld byvoorbeeld die National Covenant van 1580 soos hernu in 1590 en 1638 en die Solemn League and Covenant tussen presbiteriaan en puritein in 1843. In hierdie sin is dit uniek (vgl Schaff I 1983:685; Schaff III 1983:480ev; De Klerk 1954:81).

Wilhelmus á Brakel, moontlik die mees geleesde skrywer van die Nadere Reformasie onder die trekkers, verbind ook die taak van die staatsowerheid aan artikel 36 van die Nederlandse Geloofsbelydenis (s a I: 701). Hy plaas dit in 'n teokratiese gesagsvisie in 'n eenheidsgemeenskap waarin die owerheid die kerk van alle "overlast" in die beoefening van die godsdiens moet beskerm; verantwoordelik is vir die byeenroeping van kerkvergaderings; die ontering van die Naam van God teengaan; sabbatskending moet afweer, en moet sorg dat die evangelie oral in sy gebied verkondig word (s a I: 692-701).

Bo en behalwe die feit dat die Vetrivierreelings van die Voortrekkers hierby aansluit, spreek Andries Pretorius sy Wenkommando - soos wat dit na Bloedrivier bekend word - op 5 Desember 1838 met soortgelyke voorbeelde toe. In 'n poging om sy burgers opnuut aan God te bind, maan hy hulle om op God te vertrou, gereeld te bid, nie vroue of kinders te dood nie, nie die sabbat te ontheilig of die Naam van die Here te misbruik nie (Bantjes 14.06.1839). Die voorbeelde wat hy as militêre en politieke leier gebruik, kom opvallend ooreen met die van á Brakel.

In sy Redelijke Godsdienst bespreek á Brakel ook die aflê van geloftes of, soos hy dit ook noem, "beloftes" - die woord wat Sarel Cilliers ook vir die saak gebruik. Dat hy die saak hier hanteer, is nie ongewoon aan Calvyn en die gereformeerde tradisie nie (vgl Calvyn s a IV:13,1; Polyander 1966:45-53).

Vir á Brakel is geloftes deel van die Christelike lewe. Hy plaas dit tussen temas soos vas, sang, naasteliefde en nederigheid. Binne die raamwerk van die genadeverbond kan die gelowige hom aan God verbind om na sy wil bestuur te word. "Eene gelofte is eene verbintenis aan God, om eene particuliere goede zaak, die in onze macht is, uit vrije 
wil te doen of te laten tot dankbaerheyt of tot bevorderinge van onzen geestelijke welstand" (s a II:516).

Binne hierdie verbintenis gaan dit vir á Brakel dus om met 'n saak na God te gaan wat die toets van die lig kan deurstaan, binne die mens se vermoè is én 'n vrywillige vereenselwiging daarmee. 'n Gelofte moet egter nie ligtelik gemaak word nie en hulle wat dit doen, moet sekerheid hê dat dit nagekom kan word. Dieselfde aanhalings wat Sarel Cilliers later in sy klem op die nakoming van die gelofte van 1838 gebruik, kom by á Brakel voor: "Doet geloften en betaalt ze den Heere uwen God" (Ps 76:12) en "Het is beter dat gij niet belooft, dan dat gij belooft en niet betaalt" (Pred 5:4; vgl á Brakel s a II:517; De Jongh 1987:162).

Vir hulle soort gelofte vind die emigrante moontlik eksplisiet ruimte by á Brakel as hy verder aanvoer dat 'n gelofte deur die gelowige gebruik kan word om homself opnuut aan God te wy of om die hulp van die Here in 'n noodsituasie in te roep. Pont meen dat die gelofte van 1838 met sy binding van almal teenwoordig en hulle nageslag (ons kom straks daarby) meer korporatief as indiwidueel werk en nader aan die standpunte oor 'n gelofte in die Synopsis purioris theologiae van vier Leidse hoogleraars uit 1625 en selfs die Skotse covenants - waar leiers ander mense vir meer as een geslag bind - beweeg as aan á Brakel. Die Synopsis sou dan meer klem lê op die genadeverbond as die kader waarbinne geloftes moontlik is, lê, terwyl á Brakel op de oog af die aflê van en binding aan 'n gelofte meer indiwidueel opvat. Volgens hom openbaar laasgenoemde hier juis die invloed van die piëtisme met sy klem op die indiwidu en sy vroomheid (Pont 1988:48).

Wat Pont moontlik uit die oog verloor, is dat beide Pretorius en Cilliers die aflê van die gelofte van 1838 van indiwiduele instemming afhanklik maak. Pretorius wou dit alleen aflê "indien allen wel wilden". En hoewel daar lede van die Wenkommando was wat Cilliers se aanvanklike beswaar gedeel het dat die emigrante nie die gelofte sou nakom nie, is die gelofte eventueel met "algemeen toestemming" afgelê (Bantjes 14.06.1939; Cilliers 1876:57). By die eerste aflegging, op Sondag 9 Desember 1838 by Wasbank (De Jongh 1987:161), het Cilliers volgens eie getuienis in dieselfde trant gepraat. Nadat hy aan die aanwesiges die idee en inhoud van die gelofte verduidelik het en dit in die vooruitsig gestel het dat hulle dit in 'n gebed wat hierop sou volg, aan die 
Here sou doen, het hy aan diegene wat nie daarvoor kans sien nie, die geleentheid gegee om hulleself te verskoon (vgl Cilliers 1876:58). Hoewel hulle almal gedooptes binne 'n teokratiese opvatting was, kon indiwidue nie teen hulle gewete of wil in tot die gelofte verplig word nie. Die meriete van die saak, nie dwang nie, moes oortuig. Dit was dus 'n morele en nie 'n fisies-biologiese kwessie nie! Ons kom terug na die belofte om die saak van die gelofte aan hulle nageslag oor te dra, soos dit voorkom in die inhoud van hierdie gelofte.

'n Tweede oorweging wat in die verband voorrang aan die invloed van á Brakel verleen, is die feit dat daar ten minste sekerheid was dat die emigrante hom gelees het. Daar loop dus 'n histories aantoonbare lyn vanaf hom na persone soos Pretorius en Cilliers.

\section{DIE AFLEGGING VAN DIE GELOFTE VAN 1838}

\subsection{In 'n gebed}

Daar bestaan ' $n$ breê konsensus onder historici dat die weergawes van Pretorius en Bantjes rondom die ontstaan en aflegging van die gelofte van die belangrikste bronne in die verband is. Pretorius se weergawe kom uit 'n brief wat hy 7 dae na die Slag van Bloedrivier - op 23 Desember 1838 - aan die Voortrekkervolksraad in Natal geskryf het en wat op 16 Februarie 1839 in De Zuid-Afrikaan gepubliseer word. Behalwe dat Pretorius skryf toe die gebeure nog vars in sy geheue was, is dit bekend dat die gedagte aan die gelofte by hom ontstaan het (Liebenberg 1977:27; De Jongh 1987: 156-157) ${ }^{1}$. Hierdie faktore, sowel as die feit dat hy as die bevelvoerder van die Wenkommando die hoofmomente van die tog na Dingaanstat in Desember 1838 goed moes onthou het, beklemtoon die belang van sy brief.

As sekretaris van Andries Pretorius tydens die tog skryf Bantjes 'n journaal oor die wel en weě van die kommando. Dit verskyn op 14 Junie 1839 in De Zuid-Afrikaan. Al was hierdie stuk moontlik nie 'n dagboek wat elke dag getrou bygehou is nie, maar die verhaal kórt na die gebeure opgeteken, beklemtoon juis dit die belangrikheid daarvan.

1 Gerdener (1919:49) gaan teen Sarel Cilliers se eie getuienis in as hy die insiatief vir die gelofte aan Cilliers toeskryf. 
Daarby het Bantjes ook naby die vuur van die bevel en besluitneming in die kommando beweeg, sodat sekere besonderhede hom móés getref het.

'n Derde belangrike bron wat oorweeg moet word, is die weergawe van Sarel Cilliers. Hierdie stuk is kort voor sy dood in 1871 opgestel, waarskynlik deur Cilliers aan iemand anders gedikteer (De Jongh 1987:270, 278) en in 1876 deur Hofstede gepubliseer (Cilliers 1876). Historiese onjuisthede by Cilliers en die feit dat hy meer as dertig jaar na die slag aan die woord is, het Van Jaarsveld (1979:48) tot die slotsom laat kom dat ons hier 'n "onbetroubare herinneringstuk" het. Daarteenoor is dit bekend dat Cilliers 'n goeie geheue gehad het (De Jongh 1987:278) en dat hy tot met sy dood nie een jaar nagelaat het om die gelofte te herdenk nie (Kapp 1975:48). Boonop was die gelofte een van die hoogtepunte in sy lewe wat kon veroorsaak het dat hy die besonderhede daarvan langer as ander sake kon onthou.

Waarop dit alles op die ou end neerkom, is dat as hierdie drie figure oor 'n aspek van die gelofte saamstem, dit gewig dra. Beide Pretorius en Bantjes stel die sake rondom die gelofte bondig en in verteltrant sonder om 'n woordelikse weergawe van die gelofte self te gee. Beide meld dat die gelofte (met sy beloftes) in 'n gesamentlike gebed (waarskynlik van die kommando as geheel by die erediens op Sondagoggend 9 . Desember 1838; vgl Strauss 1994:22) aan die Here gedoen is.

Daarteenoor het Gerdener in 1919 op grond van Cilliers se weergawe probeer om die teks van die gelofte te rekonstrueer met wat hy as "nodig beskouw het" om so na aan die "oorspronkelike as molik" te kom (Gerdener 1919:68). Waarom hy sekere woorde gekies en ander weggelaat het, verduidelik hy egter nie. Hierdie teks is later deur die digter W E G Louw in "behoorlike" Afrikaans vertaal (Kapp 1975:73) en word tans algemeen by feeste en eredienste gebruik. Die Gerdenerteks (1919:67) begin met die woorde: "Mijne broeders en medelandgenooten...".

Op grond van die getuienis van Pretorius en Bantjes en die woorde waarmee Cilliers begin, het Van Jaarsveld (1979:48) en andere tot die oortuiging gekom dat Cilliers se weergawe nie betroubaar is nie. Jy bid tog nie deur jou broers en landgenote aan te spreek nie (Spoelstra 1982:7-9; Snyman \& Barnard 1992:117). Verder meen sy tweede biograaf dat Cilliers in sy journaal beweer dat die gelofte ná die gebed afgelê is (De Jongh 1987:164). 
'n Noukeurige studie van Cilliers bring aan die lig dat hy nie met Pretorius en Bantjes oor die gelofte-in-gebed verskil nie. Sy weergawe behels 'n relaas van dit wat hy aan die kommando deurgegee het vóórdat hulle die gelofte sou aflê. Hy lig hulle in oor die inhoud van die gelofte en begin dus met "Mijne Broeders en medelandgenoten..." (Cilliers 1876:121; vgl Cachet 1883:196; Liebenberg 1977:30-33). Broers, omdat hulle almal aan dieselfde kerk behoort, en landgenote, omdat hulle reeds binne 'n georganiseerde Voortrekkerstaat leef.

Dit ontbreek Van den Berg dus aan 'n basiese kennis van die historiese konteks as hy die emigrante op hierdie stadium as "landsoekers" in plaas van landgenote bestempel en die woord "medelandgenoten" by Cilliers idealisties toeskryf aan geloof in God en wat die toekoms inhou (Van den Berg 1999:29). Daarby erken hy dat die gelofte in 'n gebed gedoen is, maar behou hy hierdie aanspreekterme tog as deel van die teks van die gelofte (Van den Berg 1999:19ev).

Cilliers (1876:121) voer aan dat hy die kommando eers oor die erns en inhoud van van die gelofte ingelig het: “...hier staan wij thans, op eene Ogenblik, voor een Heilige God van Hemel en aarde...". Daarna het hy 'n beroep op hulle gedoen om in die openbare gebed wat hy nou gaan doen, met hom te deel. Eers toe het hy sy hande na die hemel opgehef om te bid "in naam van ons allen". Hierdie laaste sinsnede kom ooreen met sy woorde 'n bladsy vroeerr. Hier wys hy daarop dat daar besluit is dat hy sal voorgaan by die aflegging van die gelofte teenoor die Here "in de naam van allen..." Die gelofte is volgens hom verder "elk avond" by die drie plekke waar daar in die laer godsdiens gehou is, in die gebed bevestig (Cilliers 1876:122). Verder vertel Cilliers dat hy homself genoodsaak geag het om die aand na die slag op 16 Desember te maan teen menslike selfverheffing na "de belofte in onze gebeden aan onze Heer" (Cilliers 1876: 125). Dat die gelofte volgens Cilliers in 'n gebed gedoen is, bevestig hy ook in 'n brief aan dominee Van Broekhuizen op 14 Februarie 1866 (by Liebenberg 1977:33; De Jongh 1988:32).

Die gelofte van 1838 is dus in 'n gebed aan die Here gedoen. Maar, en dit blyk uit die verskillende weergawes van wat die inhoud daarvan sou wees: 'n teks of woordelikse weergawe daarvan is of nooit op skrif gestel nie (Bantjes sou dit dan 
moontlik in sy journaal opgeneem het!?) of het nie vir ons bewaar gebly nie. Pretorius, Bantjes én Cilliers (naas ander, vgl Spies 1988:60) gebruik telkens hulle eie woorde oor dit wat in die gelofte gevra en beloof is.

'n Eksegese van die teks van die gelofte - soos Van den Berg onlangs onderneem het - moet dus hiermee rekening hou. Naas die godsdiens- en kultuurhistoriese gaan dit hier immers óók oor die geskiedenis en die eise van die geskiedwetenskap, oor die mees waarskynlike rekonstruksie van historiese bronne.

\subsection{Die elemente van die gelofte}

'n Siftingsproses om by die hoofelemente van die geloftegebed aan die hand van die vernaamste bronne uit te kom, bring die volgende na vore. Die Here God is in die gebed aangespreek; die voorneme van 'n gelofte is genoem; oorwinning oor die onmiddellike vyand - die Zoeloekrygers van Dingane - is afgesmeek; en, as antwoord hierop is 'n jaarlikse viering van die dag van die oorwinning tot God se eer, 'n kerkgebou en die betrek van die nageslag by die saak, belowe. Omdat 'n presiese bewoording van die gelofte ontbreek, sal eksegese daarvan tot 'n soort saakeksegese beperk moet bly'.

\subsubsection{Die heilige God van hemel en aarde?}

Daar kan met redelike sekerheid aanvaar word dat die oorspronklike geloftegebed nie hierdie verwysing na God soos wat dit in Cilliers se journaal voorkom, net so gebruik het nie. Die Here is immers direk aangespreek en daar is nie in die derde persoon na Hom verwys nie.

Wat opval, is dat Cilliers in sy nagelate stukke op ander plekke in soortgelyke terme na die Here God verwys. In sy journaal vertel hy dat hy kort voor die Slag van Vegkop 'n kort "aanspraak" in die laer gehou het waarin hy daarop gewys het dat hulle 'n "Heilige God, die een Almag bekleed, in hemel en op aarde", het en dat hulle hulle voor God in gebed moet verootmoedig (Cilliers 1876:114). In 'n brief aan De Kerkbode verwys Cilliers op 11 Oktober 1865 ook na God as "de Heilige God van den hemel..." (Cilliers 1865:163). Dit wil dus voorkom asof Cilliers in die gebed voor 'n belangrike

2 Van den Berg (1999) se tekseksegese is erg pretensieus en onhistories en getuig op plekke meer van 'n volksidealisme as historiese begronding. Sodoende verword die inhoud en betekenis van die gelofte van 1838 tot iets wat dit nie bedoel is om te wees nie. 
slag waarin hy die Here aanspreek en sy hulp afsmeek, die klem op die heilige trou en almag van God kon laat val het. Daarom is dit net moontlik dat dit op 9 Desember 1838 ook kon gebeur het. Die konteks maak dit 'n logiese moontlikheid.

Heiligheid kan hier natuurlik ook op die verbondstrou van die Here slaan, hoewel daar by Vegkop nie van 'n gelofte sprake was nie. Moontlik wou Cilliers die heiligheid van God ook met verootmoediging van trekkerkant in verband bring. In sy vrye "homiletiese" eksegese van die teks van die gelofte laat Van den Berg (1999:44ev) hier die nadruk op die almag en beskikking van God - tot in die fynste detail van die lewe val. Binne die konteks is dit nie uitgesluit nie.

\subsubsection{Ons wil 'n gelofte/belofte aan $U$ maak}

By wat hierdie Emigrante-Boere onder 'n gelofte verstaan het, het ons reeds uitvoerig stilgestaan. Hoewel Cilliers, soos á Brakel, ook die woord "belofte" gebruik, verstaan beide waarskynlik daaronder wat laasgenoemde in sy Redelijke Godsdienst uiteensit. Inhoudelik verskil dit nie van wat ons vandag 'n gelofte noem nie.

In die kern van sy uitleg van wat hier met 'n gelofte bedoel word, noem Van den Berg twee sake. Beide klink oordrewe idillies en teen die verloop van die destydse spel in. Volgens hom wou die Boere hiermee sê: Nogtans nie ons wil nie, maar U wil geskied. Boonop sou dit getuig van diepe dankbaarheid teenoor God, ook vir die toekoms wat hulle van hom afsmeek (Van den Berg 1999:52). Natuurlik moes God se wil geskied, maar die afbid van 'n oorwinning dui daarop dat hulle ernstig gevra het dat juis dít God se wil sal wees. Geloftes en gebede is immers deel van God se plan. Die dankbaarheid getuig eerder van inleg as uitleg.

\subsubsection{In $\mathrm{U}$ beskerming ons vyand in ons hand sal gee}

Hierdie gedagte - dit staan nie vas dat hierdie uitdrukking van Cilliers net so in die geloftegebed gebruik is nie - vat die strategiese belangrikheid van die hele veldtog van die Wenkommando saam. Die uitkoms van hierdie veldtog waarby 464 emigrante van die manlike geslag, drie Engelse en 'n onbekende aantal swartes uit Port Natal by betrokke was (Oberholzer 1988:18ev), sou beslissend wees vir die sukses van die uittog in - op hierdie stadium - ten minste Natal. Wat wel aan die veldtog 'n ruimer betekenis 
gee, is die feit dat die grootste groep trekkers met hulle leiers vir Natal gekies het, en dat dit vir hulle 'n maak-of-breek situasie was. Sou hierdie nuwe Voortrekkermaatskappy homself kon handhaaf in sy onmiddellike omgewing?

Dat die emigrante by die Here God om beskerming en hulp teen hulle vyand, die Zoeloekrygers van Dingane soek, dui op twee kernoortuigings wat by hulle geleef het. Die eerste is dat die Here se algehele beheer en ingrype in die situasie beslissend sal wees. Hy sal die sukses van hulle veldtog bepaal (Van den Berg 1999:67). Hy is die almagtige God van hemel en aarde. Daarby is Hy die troue Bondsgod, die God van sy genadeverbond op Wie se beskerming hulle as verbondsgemeenskap kan staatmaak.

Die tweede kernoortuiging is dat God aan die kant van sy verbondskinders is. Daarom lê hulle die gelofte met vertroue af. Teenoor hulle staan daar immers nie 'n krygsmag wat daarop kan roem dat hy die Christendom of God verteenwoordig nie. Dit gaan nou om die magte van die lig teen die magte van die duisternis. Magte, so verwoord die Natalse Volksraad dit in 1841, wat op daardie stadium 'n "middel in Gods hand tot het tegengaan van moord, roof en geweld" was ('n klaarblyklike verwysing na die difaegane of binnelandse uitroeiingsoorloe waarby beide Tjaka en Dingane betrokke was; vgl Strauss 1983:36). "Ons vyand" in hierdie situasie is die vyand van die Christendom en Christelike waardes (Van den Berg 1999:68ev).

Daarom dat God se hulp afgesmeek kan word om die Zoeloes in die hande van die trekkers oor te gee. Die blote feit dat Pretorius en sy manne op hierdie stadium na die opsie van 'n gelofte gryp, beklemtoon die indruk dat hulle daarvan bewus was dat wat nou sou volg, 'n beslissende oomblik in die geskiedenis van die uittog na die binneland sou wees. En om God in hulle stryd in te roep, 'n stryd wat hulle as 'n stryd tussen lig en duisternis tipeer (vgl Olivier 1990:27), was nie vreemd aan hoe hulle op daardie stadium oor hulleself en die swart volke in die binneland gedink het nie. 'n Broerskind van Piet Retief, Anna Steenkamp, het byvoorbeeld aan die begin van die trek verklaar dat hulle 'n onderskeid tussen hulle en die swart volke maak op grond van "het natuurlijk onderschijt van afkomst en geloof" (Saamwerkers 1939:10).

Die Emigrante-Boere het om 'n oorwinning gebid, maar daarvoor ook sekere dinge aan die Here beloof. 


\subsubsection{Dié dag en datum 'n Sondag?}

Hiermee word bedoel: die dag en datum van die oorwinning.

In sy journaal het Sarel Cillliers laat opteken dat hierdie dag en datum elke jaar as 'n verjaarsdag en dankdag, "zoo als een Sabbath" tot eer van die Here gevier moes word (Cilliers 1876:121). Historiese onjuisthede by Cilliers en die feit dat hierdie sogenaamde sabbatsklousule nie ook by Pretorius, Bantjes en ander getuienis oor die gelofte (vgl Spies 1988:60) voorkom nie, het sommige tot die oortuiging laat kom dat die klousule nie in die oorspronklike gelofte was nie (Snyman \& Barnard 1992: 118).

Pretorius (16.02.1839) praat van 'n dag wat aan die Here toegewy en met "Dankzeggingen" gevier moet word. Bantjes (14.06.1839) noem dit 'n dag wat tot "Eere van God" herdenk moet word. Die interessante is dat begrippe soos 'n dankdag en 'n dag tot eer van God gevier ook by Cilliers voorkom. In sy brief aan ds Van Broekhuizen in 1866 gebruik Cilliers nie die uitdrukking "zoo als een Sabbath" nie, maar maak hy gewag van "een bid en gedenk en dankdag" (Cilliers 1866). Dit versterk die afleiding dat Cilliers met sy terme nie op 'n drie en vyftigste mensgemaakte Sondag afstuur nie, maar eerder wil aantoon in watter gees die dag deurgebring moes word (vgl De Jongh 1988:32; Duvenage 1988:166-167).

Dat hierdie gees met hulle wyse van Sondagviering (sóós 'n sabbat) moes ooreenkom, word onderstreep deur die uitdrukkings "aan die Here toegewy" (as dag van die Here jou God?) van Pretorius en "tot eer van God" gevier moet word van Bantjes. Gedagtig aan die feit dat die trekkers ryklik uit die tradisie van die Nadere Reformasie met sy wettiese elemente geput het, is dit kwalik moontlik om dit anders te sien. 'n Wettiese benadering van die Sondag openbaar daarby dikwels ook 'n verknogtheid aan die Ou Testamentiese "sabbat".

In aanvulling hierby is dit interessant dat die Voortrekkerpredikant, Erasmus Smit, die gelofte op die Sondag naaste aan 16 Desember herdenk het (De Natalier 13.12.1844). Ook het ds Frans Lion Cachet, een van die inisieerders van die eerste betrokkenheid van die Ned Geref Kerk van Natal in 1864 by die vieringe, geen teenstrydigheid tussen die weergawes van Cilliers aan die een en Pretorius en Bantjes aan die ander kant gesien nie (vgl Cachet 1875:146-147 met Cachet 1883:196). Vir sy 
vertolking van die gebeure was Cachet ook in kontak met mense wat die Slag van Bloedrivier self meegemaak het (Van Jaarsveld 1987:46).

As die Nasionale Regering in 1952 dus sekere bepalings van die "sabbatswetgewing" op Geloftedag (die Regering aanvaar hierdie naam vir 16 Desember hier amptelik) as 'n godsdienstige feesdag soos Goeie Vrydag en Kersdag, van toepassing maak, klop sy vertolking met hierdie geskiedenis. Volgens die betrokke minister wou hulle nie hiermee 'n mensgemaakte "sabbat" skep nie, maar bloot die ware karakter van die dag duideliker laat uitkom (Debatte in die Volksraad dele 74-76:10435-10438).

\subsection{5 'n Huis ter herinnering aan sy groot Naam}

Beide Pretorius en Bantjes praat van die stigting of bou van 'n huis tot gedagtenis of herinnering aan die groot Naam van die Here (vgl 16.02.1839; 14.06.1839). Hoewel Cilliers die bou van 'n kerk in sy journaal uitlaat, vermeld hy dit wel in sy brief aan ds Van Broekhuizen. Hier gebruik hy die gewone terme naamlik "dat wij ook de Heer een Kerk zal bouwen in ons midden" (by De Jongh 1987:163).

Die kwessie van 'n huis of kerk ter herinnering aan die Naam van God kan na twee kante toe uitval. Die eerste een is dat hierdie herinnering gekoppel word aan God se uitredding deur 'n oorwinning ná die gelofte aan die trekkers te gee. Die grootheid van sy Naam is dus opnuut geillustreer deur sy magtige ingrype om die uittog van sy bondelinge na Natal te red. Die tweede is dat die visualisering van 'n kerk daarop dui dat die emigrante as 'n Christelike gemeenskap permanente vestiging in pioniersomstandighede beoog. In hierdie proses sou die dringende bou van 'n kerk ook die bou van hierdie nuwe samelewing op Christelike waardes én die strewe om hierdie waardes uit te dra, kon simboliseer (vgl Olivier 1990:67).

Bantjes beweer dat die huis gebou moes word op 'n plek wat die Here behaag, terwyl Pretorius gewag maak van 'n plek wat die Here sal aanwys. Daar is sommige (vgl Marais 1996:16; Van den Berg 1999:110) wat hierdie behaag verbind met "oral waar dit Hom behaag". Volgens hulle dui dit daarop dat daar kerke gebou moes word oral waar dit God behaag om Afrikaners te vestig - 'n proses wat tot op vandag nog moet voortgaan. Nie Pretorius, Bantjes of Cilliers bevestig egter enige vermoedens in die verband nie. Boonop is dit net moontlik dat Cilliers die oprigting van 'n kerk in sy 
journaal uitlaat omdat dit syns insiens reeds met die oprigting van die Geloftekerk in Pietermaritzburg uitgevoer is (Oberholzer 1988:22). Dit was teen 1871 dus nie meer 'n kwessie nie.

Indien aanvaarding van die gelofte ook 'n aanvaarding van Christelike lewenswaardes inhou, is die bou van kerke oral waar hierdie soort mens vestig, natuurlik 'n logiese konsekwensie.

\subsubsection{Ons nageslag ook betrek}

Hoewel hulle dit verskillend bewoord, is dit duidelik dat Pretorius, Bantjes en Cilliers daarvan oortuig was dat die nageslag by die viering van die dag betrek moes word. Pretorius stel dit dat die betekenis van die dag aan "ons gansche geslacht" bekend gemaak moes word ter wille van die toekomstige viering daarvan (16.02.1839). Bantjes stel 'n boek waarin alles opgeteken word, in vooruitsig, sodat selfs "onze laatste nageslachten" kan deel in die viering (14.06.1839). Cilliers praat van "onzen" kinders en opkomende geslagte wat oor die gebeure ingelig moes word sodat hulle daarin kon deel (1876:121).

Oor wat ons onder "ons nageslag" moet verstaan, loop die weě uiteen, Sommige wil dit koppel aan die nageslag van die Voortrekkers by Bloedrivier (Marais 1996:18-19; Van den Berg \& Botha 1994:1096). 'n Populêre siening neem dit ruimer: dit gaan oor alle Afrikaners. Nog ander meen dat die uitkoms van Bloedrivier tot voordeel van die Christelike beskawing en -waardes van almal in hierdie land was, dat die trekkers by hierdie geleentheid verteenwoordigend genoeg is en dat die gelofte dus "algemene en landsbindende krag" het (Olivier 1990:30-31) of almal insluit wat burgerreg in SuidAfrika het (Engelbrecht 1988:32).

Om historiese en ander redes erken Marais en Van den Berg \& Botha - ons het reeds op beide Cilliers en Bantjes se opmerkings in die verband gewys - dat die aflegging van die gelofte in 1838 vrywillig was. Niemand kon op daardie stadium teen sy gewete of wil in by so iets betrek word nie. Die nageslag van diegene wat ingestem het, het volgens hierdie skrywers egter nie meer 'n keuse nie. Hulle word, sonder dat hulle in die saak geken hoef te word, gebind aan die vrywillige keuse van hulle voorouers. 
Hierdie standpunt bots egter lynreg met die standpunt van die Algemene Sinode van die Ned Geref Kerk van 1990 wat praat van 'n morele binding. Die kommissie wat aan die sinode rapporteer, oordeel onomwonde dat "niemand 'n ander mens deur 'n gelofte kan bind nie". Daarom is slegs hulle aan die gelofte van 1838 gebind wat hulle deur die saak waarvoor dit staan, aangespreek voel (NGK 1990:116, 560).

Dit is natuurlik vreemd om aan die oorspronklike afleggers 'n keuse te gee, maar dit aan diegene wat na hulle kom, te ontsê. Veral as jy soos die laaste twee outeurs boonop daaraan toevoeg dat alle lede van die nageslag wat intussen iewers by 'n fees hulle tot die gelofte van 1838 verbind het, in elke geval daaraan gebonde is (Van den Berg \& Botha 1994:1037). Dan gee jy mos die beginsel van 'n vrywillige assosiasie omdat die saak jou moreel aanspreek en jy dit daarom nie kan ignoreer nie, toe.

Dit is te betwyfel of 'n gelofte soos hier afgelê, op dieselfde vlak lê as God se verbond van genade met die gelowiges en hulle kinders. Hier gaan dit om menslike inisiatief en menslike oordeel - iets wat jy die nageslag nie kan ontsê nie. Juis á Brakel praat van 'n assosiasie uit "vrije wil" (s a II:516). Daarteenoor sluit God sy genadeverbond met die gelowiges en hulle kinders op sy inisiatief. Dit kom monopleuries tot stand en vorm die noodsaaklike bedding waarbinne God die mens en sy nageslag red. Dit bevat beloftes en eise wat oorgaan van geslag na geslag.

Die gelofte van 1838 bind nie fisies-biologies nie, maar moreel. Verder gaan dit hier om mense waarmee feitlik alle latere Afrikaners - en diegene wat met hulle assosicer - vrywillig vereenselwig het. In hierdie Afrikaners het hulle hulleself verteenwoordig gesien. Omdat dit by die gelofte gaan om die verbintenis van gelowige Afrikaners aan Christelike lewenswaardes terwyl hulle op die almagtige God vertrou, moet enige Christen-Afrikaner wat homself hiervan verskoon, goeie redes verskaf. Want, deur sy afwesigheid versaak hy sy Christelike plig. Dat hierdie verbintenis nie uit en uit indiwidueel is nie - dit warvoor Pont sku is - blyk daaruit dat dit 'n kollektiewe band met die Christendom en die Afrikaner impliseer. Die argument van 'n landsbinding van die gelofte negeer egter hierdie historiese lyn. Bowendien sal dit nie realiseer nie. 
Van Van den Berg (1999:42) cordeel dat dit onsinnig is om oor die nakoming van die gelofte te worstel met mense wat nie Bybelgelowige Afrikaners is nie en vir wie die heiligheid van die God aan Wie hierdie gelofte in 1838 gemaak is, dus niks sê nie.

\section{IMPLIKASIES VAN DIE GELOFTE VIR VANDAG}

Die Suid-Afrika van die jaar 2000 verskil radikaal van die van die trekkermaatskappy waarin die gelofte van 1838 afgelê is. Van 'n teokratiese verbondsgemeenskap waarin kerk en staat twee kante van dieselfde gemeenskap vorm, is daar nie meer sprake nie. Christen-Afrikaners maak nie meer die enigste lede van hierdie gemeenskap uit nie.

En tog sou Christen-Afrikaners en diegene wat met hulle assosieer, hulle steeds met die saak agter die gelofte en daarom die gelofte self, kon vereenselwig én daaraan in ons eie tyd opnuut gestalte gee. Ek verwys spesifiek na die verbintenis tot die uitleef van Christelike lewenswaardes in vertroue op God.

In 1838 was kerk, staat en volk in 'n eenheidsgemeenskap betrokke by die uitlewe van die gelofte. Dit het gegaan om gelowige Afrikaners (dit is onwaarskynlik of, ten minste, onseker of die drie Engelse uit Port Natal en hulle swartes by die saak betrek is, vgl Olivier 1990:50) wat onder leiding van 'n ouderling hulle self vir 'n militêre operasie, eie aan die staat, gereed gekry het.

In ons situasie vandag kan Christen-Afrikaners steeds draers van die Woord as verlossingsboodskap en basis vir Christelike lewenswaardes wees. Gekoppel aan die Christen-Afrikaner as 'n groep en die impak van hierdie waardes op die res van die samelewing, word 16 Desember 'n tyd vir 'n geestelike voorraadopname onder Afrikaners en die Suid-Afrikaanse gemeenskap waarin hulle hulle bevind. So klop dit met die bres wat Bloedrivier vir die vestiging van Christelike samelewingswaardes in die destydse binneland geslaan het.

Bloedrivier en die herdenking van die gelofte gaan nie oor 'n rassistiese verlekkering van witmense oor die neerlaag van swartmense nie. Met sy verbintenis aan God en Bybelse lewenswaardes kan die gelofte Christenmense opnuut motiveer om op basis van die Bybel met mekaar en ander in hierdie land te versoen.

Die gelofte en Bloedrivier staan ook sentraal en gemeenskaplik in ChristenAfrikaners se verstaan van hulle eie volkswees. Daarom dat die son elke 16 Desember 
om 12:00 op die senutaaf in die Voortrekkermonument in Pretoria moet val. Kultuurbelewing op 'n Christelike grondslag en in 'n eietydse idioom kan dus deel wees van die viering van hierdie dag.

Wat die staat betref, kan daar met reg van die huidige owerheid verwag word om die regsruimte te verskaf waarbinne die herdenking van die gelofte moontlik is. En, omdat die owerheid, enige owerheid, 'n dienaar van God tot ons beswil is - Romeine 13 - en dit hier gaan om Christelike waardes, moet hy hom ook aan God se bepalings vir die reg hou. Die gelofte van 1838 is moreel bindend, histories verantwoord en nie gedateer nie.

\section{Literatuurverwysings}

Á Brakel, W s a I en II. Redelijke Godsdienst. Rotterdam: D Bolle.

Bantjes, J 1839. De uitgewekene Boeren te Port Natal. De Zuid-Afrikaan 14 Junie 1839. Botha, S J 1988. Die Gelofte van 1838 soos dit in 1880 by Paardekraal met 'n belofte bevestig is, in Pont, A D (red), Die Gelofte van 1838, 63-82. Pretoria: Kital.

Brown, E 1990. Kantaantekeninge by 'n boekeversameling van 'n $19^{\circ}$-eeuse gemeente. NGTT 30(4), 533-554.

Cachet, F L 1875. Vijftien jaar in Zuid-Afrika. Leeuwarden: H Bokma.

Cachet, F L 1883. De worstelstrijd der Transvalers. 2e druk. Amsterdam: Höveker en Zoon.

Calvyn, J s a. Institusie III en IV, vertaal deur Sizoo, A. 4e druk. Delft: W D Meinema. Cilliers, S A 1865. Brief aan De Kerkbode 11 Oktober 1865, in Gerdener, G B A 1919, Sarel Cilliers, die vader van Dingaansdag, 163-166. Kaapstad: Samuel Griffiths. Cilliers, S A 1866. Brief aan ds van Broekhuizen (14.02.1866). Lêer A 121, Argiefbewaarplek, Bloemfontein.

Cilliers, S A 1876. Journaal, in Gerdener, G B A 1919, Sarel Cilliers, die vader van Dingaansdag, 112-132. Kaapstad: Samuel Griffiths.

Debatte in die Volksraad, dele 74-76.

De Jongh, P S 1977. Die lewe van Erasmus Smit. Pretoria: HAUM.

De Jongh, P S 1987. Sarel Cilliers. Johannesburg: Perskor. 
De Jongh, P S 1988. Perspektiefstelling oor omstrede aangeleenthede van die Groot Trek. Historia 33(2), 27-37.

De Klerk, P J S 1954. Gereformeerde Simboliek. Pretoria: JL van Schaik.

De Natalier, 1844.

Du Bruyn, J T s a. Die Groot Trek, in Cameron, T (red), Nuwe geskiedenis van SuidAfrika in woord en beeld, 127-139. Kaapstad: Human en Rousseau.

Duvenage, G D J 1988. Die Gelofte. Pretoria: Afrikanervolkswag.

Engelbrecht, B J 1988. Geloftedag - 'n analise, in Pont, A D (red), Die Gelofte van 1838, 27-37. Pretoria: Kital.

Gerdener, G B A 1919. Sarel Cilliers, die vader van Dingaansdag. Kaapstad: Samuel Griffiths.

Hofmeyr, J W 1989. Die Nederlandse Nadere Reformasie en sy invloed op twee kontinente. Pretoria: Unisa.

Kapp, P H 1975. Geloftefees, in Grobbelaar, P W (red), Die Afrikaner en sy kultuur, Deel III: Ons volksfeeste, 46-97. Kaapstad: Tafelberg.

Liebenberg, B J 1977. Andries Pretorius in Natal. Pretoria: Academica.

Malan, C J 1984. Die Nadere Reformasie. Potchefstroom: PU vir CHO.

Marais, W 1996. Geloftedag en die Afrikaner. Pretoria: Anrics.

Ned Geref Kerk, 1994. Handelinge van die Algemene Sinode. Sl:sn.

Ned Geref Kerk 1998. Handelinge van die Algemene Sinode. Sl:sn.

Oberholzer, J P 1988. 1835-1838: 'n Kort oorsig oor die aanloop tot die Gelofte en die Slag van Bloedrivier, in Pont, A D (red), Die Gelofte van 1838, 1-26. Pretoria: Kital.

Olivier, S P 1990. Folus op Gelofte. Pretoria: NG Kerkboekhandel.

Polyander, J 1966. Over de geloften, in Synopsis (2) of oversicht van de zuiverste theologie, 45-53, vertaal deur D van Dijk. Enschede: J Boersma.

Pont, A D 1986. Verbond en volkskerk. HTS 42(1), 28-76.

Pont, A D 1988. Die Gelofte van 1838 - 'n poging om die teologiese agtergrond daarvan te peil, in Pont, A D (red), Die Gelofte van 1838, 38-53.

Preller, G S 1920. Voortrekkermense, I. Kaapstad: Nasionale Pers.

Pretorius, A W J 1839. Brief aan Volksraad. De Zuid-Afrikaan 16 Februarie 1839. 
Saamwerkers, 1939. Die dagboek van Anna Steenkamp en fragmentjies oor die Groot Trek. Pietermaritzburg: Die Natalse Pers.

Schaff, P 1983. The creeds of the Christendom, I and III. Grand Rapids: Baker.

Smit, E 1897. Dagboek (geredigeer deur Schoon, HF). Kaapstad: Townshend, Taylor and Snashall.

Snyman, S D \& Barnard, S L 1992. Gedagtes oor Geloftedag. Acta Theologica 12(2), 113-119.

Spoelstra, B 1982. Kan Geloftedag oorlewe? Potchefstroom: PU vir CHO.

Strauss, P J 1983. Die Ned Geref Kerk en die Gereformeerde Kerke in Nederland: Betrekkinge rondom die Suid-Afrikaanse rassevraagstuk. DD-proefskrif, Universiteit van Pretoria.

Strauss, P J 1994. Geloftedag in die "nuwe" Suid-Afrika. Bloemfontein: Drufoma.

Van den Berg, M 1999. Geloftesterk jou stand. Pretoria: Radio Pretoria.

Van den Berg, D v R \& Botha, S J 1994. Die ontstaan en die doel van die Voortrekkers se gelofte van 1838. HTS 50(4), 1018-1040.

Van der Watt, P B 1986. Die Nederduitse Gereformeerde Kerk 1652-1824. 2e druk. Pretoria: NG Kerkboekhandel.

Van Jaarsveld, F A 1979. Die evolusie van apartheid en ander geskiedkundige opstelle. Kaapstad: Tafelberg.

Van Jaarsveld, F A 1987. Die cerste openbare viering van 16 Desember. Tydskrif vir Geesteswetenskappe 27(1), 42-49.

Van 't Spijker, W 1986. De Nadere Reformatie, in Van 't Spijker, W (red), De Nadere Reformatie: Beschrijving van haar voornaamste vertegenwoordigers. Den Haag: Boekencentrum. 